\title{
RNR1 wt Allele
}

National Cancer Institute

\section{Source}

National Cancer Institute. RNR1 wt Allele. NCI Thesaurus. Code C53148.

Human RNR1 wild-type allele is located in the vicinity of $13 p 12$ and its length is unknown.

This allele, which encodes RNA, ribosomal 1, plays a role in the mediation of both ribosomal structure and protein translation. 